\title{
Hubungan Perilaku Merokok dengan Ketahanan Kardiorespirasi (Ketahanan Jantung-Paru) Siswa SMKN I Padang
}

\author{
Amanda Besta Rizaldy ${ }^{1}$, Afriwardi ${ }^{2}$, Yessy Susanty Sabri ${ }^{3}$
}

\begin{abstract}
Abstrak
Ada banyak faktor yang dapat mempengaruhi ketahanan kardiorespirasi pada remaja, salah satunya adalah perilaku merokok. Merokok pada masa remaja akan mengganggu kebugaran, khususnya ketahanan kardiorespirasi karena efek dari zat yang terkandung didalamnya. Tujuan penelitian ini adalah menentukan hubungan perilaku merokok dengan ketahanan kardiorespirasi pada remaja. Ini merupakan penelitian analitik dengan desain crosssectional study yang dilakukan pada siswa Sekolah Menengah Kejuruan Negeri 1 Padang (SMK N 1 Padang) dengan jumlah subjek sebanyak 111 orang. Pengumpulan data melalui kuesioner dan tes ketahanan kardiorespirasi. Analisis statistik yang digunakan adalah uji chi-square. Hasil penelitian menunjukkan bahwa sebagian besar siswa SMK N 1 Padang yang merokok memiliki ketahanan kardiorespirasi yang kurang baik yaitu sebanyak $55,1 \%$ siswa, sedangkan sebanyak 40,5\% pada siswa yang tidak merokok memiliki ketahanan kardiorespirasi yang cukup baik. Setelah dilakukan analisis melalui uji chi-square, disimpulkan bahwa terdapat hubungan antara perilaku merokok dengan ketahanan kardiorespirasi $(p<0,05)$.
\end{abstract}

Kata kunci: perilaku merokok, ketahanan kardiorespirasi, remaja

\section{Abstract}

There are many factors correlate to cardiorespiratory endurance of the teenagers, one of them is smoking behavior. Smoking behavior in teenagers will affect the physical fitness, especially for the cardiorespiratory endurance because of the effect from the substances in cigarette. The objective of this study was to determine the correlation between smoking behavior and the cardiorespiratory endurance of the teenagers. This was an analytical research with cross-sectional study design. This study was done for the students of Vocational Senior High School 1 Padang with the total subjects were 111 peoples. The data was collected by questionnaire and cardiorespiratory endurance's test. This study used chi-square test for the statistical analyze. The result of this research found that most of the smoker students of SMK N 1 Padang have a low cardiorespiratory endurance, the percentage was 55,1\% and 40,5\% of the non-smoker students had a good enough cardiorespiratory endurance. The chi-square test result conclude that there is a significant relation between smoking behavior and the cardiorespiratory endurance $(p<0,05)$.

Keywords: smoking behavior, cardiorespiratory endurance, teenagers

Affiliasi penulis: 1. Pendidikan Dokter FK UNAND (Fakultas Kedokteran Universitas Andalas Padang), 2. Bagian Fisiologi FK UNAND, 3. Bagian Paru FK UNAND

Korespondensi :Amanda Besta Rizaldy, Email: abestarz@gmail.com Telp: 085363011075

\begin{abstract}
PENDAHULUAN
Semua bentuk kegiatan manusia selalu memerlukan dukungan fisik, karena kemampuan fisik merupakan faktor dasar bagi setiap aktifitas manusia.
\end{abstract}


dalam menjalankan kehidupan sehari-hari. Setiap orang tidak akan lepas dari kebugaran jasmani, karena kebugaran jasmani merupakan salah satu faktor yang sangat penting dalam menjalankan kehidupan sehari-hari. Tingkat kebugaran jasmani dipengaruhi oleh banyak faktor, salah satunya merokok yang dapat mempengaruhi kebugaran jasmani remaja. ${ }^{1}$

Merokok merupakan perilaku yang merugikan kesehatan, namun jumlah perokok justru semakin bertambah. Di Indonesia, perilaku merokok dianggap sebagai kebiasaan yang sangat wajar. Perilaku merokok tidak pernah surut karena merupakan perilaku yang masih dapat ditolerir oleh masyarakat. Hal ini dapat dilihat dalam kehidupan sehari-hari di lingkungan rumah, kantor, angkutan umum maupun di jalan-jalan. Hampir setiap saat dapat disaksikan dan dijumpai orang yang sedang merokok, bahkan di lingkungan pendidikan. ${ }^{2}$

Di Indonesia kegiatan merokok seringkali dilakukan individu dimulai di sekolah menengah pertama, bahkan mungkin sebelumnya. Usia pertama kali merokok umumnya berkisar antara usia 11-13 tahun dan mereka pada umumnya merokok sebelum usia 18 tahun. $^{3}$ Hasil riset kesehatan Indonesia tahun 2013 memperlihatkan prevalensi perokok di Indonesia sebesar 29,3\% dari jumlah penduduk dan $11,2 \%$ dari perokok mulai merokok sejak usia remaja yaitu 15-19 tahun, sedangkan usia tersebut dapat dikategorikan termasuk dalam rentangan masa remaja. $^{4}$

Sekarang ini kebiasaan merokok aktif pada anak cenderung meningkat dan dimulai pada usia semakin muda, yaitu pada masa akhir usia sekolah atau masa remaja. Penelitian Universitas Andalas dengan responden di kecamatan Padang Barat tahun 2004 menunjukkan bahwa sebesar 97,7\% anak memulai merokok pada usia di bawah 16 tahun.,

Jumlah perokok dunia mencapai 1,35 miliar orang. Indonesia merupakan salah satu negara dengan jumlah perokok terbesar di dunia. Data World Health Organization (WHO) pada tahun 2008, dapat disimpulkan bahwa Indonesia menempati urutan ketiga setelah China dan India pada sepuluh negara perokok terbesar dunia. ${ }^{7}$ Jumlah perokok Indonesia mencapai 146 juta jiwa pada tahun 2009 dengan $13,2 \%$ dari total keseluruhan remaja di Indonesia adalah perokok aktif. Persentase remaja yang merokok di Indonesia merupakan yang tertinggi jika dibandingkan dengan persentase tertinggi remaja yang merokok di negara lain sebesar $11 \%{ }^{8}$

Prevalensi perokok di Indonesia pada tahun 2013 sebesar 29,3\%, dengan jumlah perokok pada laki-laki sebanyak $47,5 \%$ dan perempuan $1,1 \%$. Provinsi Sumatera Barat menempati urutan kedelapan dari sepuluh provinsi dengan jumlah perokok terbesar di Indonesia. Persentase penduduk yang merokok mencapai $26,4 \%$. Persentase ini dihitung berdasarkan jumlah penduduk usia di atas 10 tahun. Sedangkan untuk persentase perokok remaja dapat dilihat dari jumlah perokok yang berusia 15-19 tahun, yaitu mencapai $11,2 \%$. Pelajar SMA/SMK berada dalam rentang usia tersebut. ${ }^{4}$

Merokok pada masa remaja akan mengganggu perkembangan paru-paru, salah satunya adalah munculnya penyakit asma pada anak dan remaja. Karena masih muda, sistem saraf sedang berkembang sehingga racun rokok mengganggu perkembangan kesehatan mental seperti mudah gelisah dan depresi. ${ }^{9}$

Penelitian mengenai pengaruh rokok terhadap kebugaran jasmani perlu untuk dilakukan, karena jumlah perokok remaja yang semakin meningkat. Peningkatan jumlah perokok remaja dikhawatirkan menurunkan kualitas generasi penerus bangsa. Hal tersebut dikarenakan merokok dapat mempengaruhi kebugaran tubuh. Kebugaran tubuh bagi remaja dibutuhkan karena mereka dalam masa pendidikan dan masa produktifitas. Penurunan kebugaran tubuh dimungkinkan akan mempengaruhi prestasi belajar para remaja.

\section{METODE}

Penelitian ini merupakan penelitian analitik dengan menggunakan desain cross-sectional study, yaitu menentukan hubungan perilaku merokok dengan ketahanan kardiorespirasi siswa SMK N 1 Padang.

Data perilaku merokok subjek didapatkan melalui kuesioner yang dikutip dari Global Youth Tobacco Survey (GYTS). Data ketahanan kardiorespirasi subjek didapatkan dari tes ketahanan 
kardiorespirasi menggunakan Harvard Step Test. Analisis hasil penelitian ini menggunakan uji statistik chi-square test dengan tingkat pemaknaan $p<0,05$.

\section{HASIL}

\section{Karakteristik Subjek Penelitian}

Subjek dalam penelitian ini adalah siswa SMK N 1 Padang dengan jumlah sampel yang diambil sebanyak 111 orang siswa. Semua subjek pada penelitian ini berjenis kelamin laki-laki dan tidak terdapat subjek yang menderita gangguan kardiorespirasi pada penelitian ini.

Pada penelitian ini, subjek penelitian usia 17 tahun lebih banyak dibandingkan dengan usia lainnya yaitu sebesar 57 atau $51,4 \%$ dan diikuti oleh usia 18 tahun sebesar 36 atau 32,4\%, untuk distribusi subjek yang mulai merokok terbanyak terdapat pada usia 12 -15 tahun yaitu sebanyak $64 \quad(57,7 \%)$ siswa, sedangkan untuk 42 orang siswa atau $21,6 \%$ didapatkan tidak pernah mencoba untuk merokok. Berdasarkan durasi merokok dalam satu bulan, sebanyak $42(37,8 \%)$ siswa untuk durasi 0 hari atau bisa dikatakan tidak pernah mengonsumsi rokok, 25 $(22,5 \%)$ siswa merokok dengan durasi 1 - 5 hari, 17 $(15,3 \%)$ siswa dengan durasi $6-19$ hari dan sebanyak $27(24,3)$ siswa merokok dengan durasi 20 30 hari. Dari keseluruhan subjek penelitian, terdapat $42(37,8 \%)$ siswa dengan frekuensi merokok sebanyak 0 batang atau tidak merokok, sedangkan untuk siswa yang merokok terbanyak didapatkan 62 siswa $(55,9 \%)$ merokok 1 - 10 batang per hari. Untuk lama waktu merokok pada siswa yang merokok, ditemukan siswa terbanyak memiliki lama merokok 3 - 5 tahun yaitu sebanyak 31 orang (27,9\%) dan 42 siswa atau $37,8 \%$ dari 111 sampel didapatkan tidak merokok.(Tabel 1a dan 1b)

Tabel 1a. Karakteristik subjek penelitian

\begin{tabular}{cc}
\hline \multicolumn{1}{c}{ Karakteristik } & Jumlah \\
\hline Usia & $1(0,9 \%)$ \\
15 tahun & $10(9 \%)$ \\
16 tahun & $57(51,4 \%)$ \\
17 tahun & $36(32,4 \%)$ \\
18 tahun & $7(6,3 \%)$ \\
19 tahun & \\
\hline
\end{tabular}

Tabel 1b. Karakteristik subjek penelitian

\begin{tabular}{lc}
\hline \multicolumn{1}{c}{ Karakteristik } & Jumlah \\
\hline Usia mulai merokok & \\
Tidak pernah merokok & $42(21,6 \%)$ \\
$<7$ tahun & $5(4,5 \%)$ \\
$8-11$ tahun & $18(16,2 \%)$ \\
$12-15$ tahun & $64(57,7 \%)$ \\
Durasi merokok & \\
0 hari (tidak merokok) & $42(37,8)$ \\
$1-5$ hari & $25(22,5 \%)$ \\
$6-19$ hari & $17(15,3 \%)$ \\
$20-30$ hari & $27(24,3 \%)$ \\
Frekuensi merokok & \\
0 batang (tidak merokok) & $42(37,8 \%)$ \\
$1-10$ batang & $62(55,9 \%)$ \\
$11-20$ batang & $6(5,4 \%)$ \\
$>20$ batang & $1(0,9 \%)$ \\
Lama merokok & \\
0 tahun (tidak merokok) & $42(37,8 \%)$ \\
$1-2$ tahun & $10(9 \%)$ \\
$3-5$ tahun & $31(27,9 \%)$ \\
$>5$ tahun & $28(25,2 \%)$ \\
\hline
\end{tabular}

Berdasarkan sampel yang ada, dari 111 orang siswa, sebanyak 42 siswa $(37,8 \%)$ tidak merokok dan sebanyak 69 siswa $(62,2 \%)$ merokok.

Tabel 2. Perilaku merokok

\begin{tabular}{lcc}
\hline \multicolumn{1}{c}{ Kelompok } & $\mathbf{n}$ & $\%$ \\
\hline Tidak Merokok & 42 & 37,8 \\
Merokok & 69 & 62,2 \\
\hline Total & 111 & 100
\end{tabular}

Keterangan: $\mathrm{n}=$ jumlah sampel, $\%=$ persentase kejadian.

\section{Ketahanan Kardiorespirasi}

Berdasarkan ketahanan kardiorespirasi pada didapatkan sebanyak 38 (34,2\%) kurang baik, 21 siswa (18,9\%) sedang, 25 siswa $(22,5 \%)$ cukup, 9 siswa $(8,1 \%)$ baik dan sebanyak 18 (16,2\%) siswa mempunyai ketahanan kardiorespirasi yang sangat baik.

Tabel 3. Ketahanan kardiorespirasi

\begin{tabular}{lcc}
\hline \multicolumn{1}{c}{ Kelompok } & $\mathbf{n}$ & $\%$ \\
\hline Kurang Baik & 38 & 34,2 \\
Sedang & 21 & 18,9 \\
Cukup & 25 & 22,5 \\
Baik & 9 & 8,1 \\
Sangat Baik & 18 & 16,2 \\
\hline Total & 111 & 100 \\
\hline Keterangan: $n=$ jumlah sampel, \%= persentase kejadian.
\end{tabular}




\section{Hubungan Perilaku Merokok dengan Ketahanan Kardiorespirasi}

Proporsi siswa yang merokok dengan ketahanan kardiorespirasi pada kelompok kurang baik, sedang dan cukup adalah sebanyak 63 siswa atau sebanyak $91,3 \%$ dari keseluruhan siswa yang merokok, 6 siswa atau 8,7\% memiliki ketahanan kardiorespirasi pada kelompok baik dan sangat baik dari keseluruhan siswa yang merokok. Ketahanan kardiorespirasi pada subjek yang tidak merokok sebanyak 21 siswa atau 50\% memiliki ketahanan kardiorespirasi pada kelompok kurang baik, sedang, dan cukup, sedangkan 21 orang atau 50\% siswa lainnya memiliki ketahanan kardiorespirasi pada kelompok baik dan sangat baik.

Tabel 4. Hubungan perilaku merokok dengan ketahanan kardiorespirasi

\begin{tabular}{cccccc}
\hline \multirow{2}{*}{$\begin{array}{c}\text { Ketahanan } \\
\text { Kardiorespirasi }\end{array}$} & \multicolumn{4}{c}{ Merokok } & \multicolumn{3}{c}{ Tidak Merokok } & \\
\cline { 2 - 5 } & $\mathbf{n}$ & $\%$ & $\mathbf{n}$ & $\%$ & \\
\hline $\begin{array}{c}\text { Kurang Baik - } \\
\text { Sedang - Cukup } \\
\text { Baik - Sangat } \\
\text { Baik }\end{array}$ & 63 & 91,3 & 21 & 50,0 & 0,000 \\
\hline Total & 6 & 8,7 & 21 & 50,0 & \\
\hline
\end{tabular}

Keterangan: $n=$ jumlah sampel, $\%=$ persentase kejadian

Pada hasil pengolahan data menggunakan $C h i$ Square, pada tabel diatas dapat dilihat nilai $p=0,000$ (dimana nilai $p$ yang dianggap bermakna adalah $p<$ 0,05), yang artinya terdapat perbedaan yang bermakna antara ketahanan kardiorespirasi pada siswa yang merokok dengan siswa yang tidak merokok. Artinya, siswa yang merokok cenderung mempunyai ketahanan kardiorespirasi yang kurang baik dibandingkan dengan siswa yang tidak merokok.

\section{PEMBAHASAN}

\section{Hubungan Perilaku Merokok dengan Ketahanan Kardiorespirasi}

Hasil uji statistik menunjukkan terdapat hubungan yang bermakna antara perilaku merokok dengan ketahanan kardiorespirasi, maknanya, pada subjek yang merokok didapatkan memiliki ketahanan kardiorespirasi yang kurang baik. Hasil ini sejalan dengan penelitian yang dilakukan oleh Rahmawati, pada remaja di Serang Banten tahun 2009 menunjukkan ada hubungan antara konsumsi rokok dengan kebugaran. ${ }^{10}$ Penelitian lain yang dilakukan oleh Budiasih pada tahun 2011 yaitu terdapat hubungan antara perilaku merokok dengan kebugaran jasmani yang pengukuran tingkat ketahanan kardiorespirasinya sama-sama diukur dengan Harvard Step Test. ${ }^{11}$

Zat yang terkandung dalam rokok seperti nikotin dapat mengganggu sistem saraf simpatis dengan akibat meningkatnya kebutuhan oksigen miokard. Bahan ini meningkatkan kebutuhan oksigen dan juga mengganggu suplai oksigen ke otot jantung (miokard) sehingga merugikan kerja miokard. semakin banyak rokok dihisap, semakin hebat jantung dipacu. ${ }^{12}$ Pada zat lainnya seperti karbon monoksida (CO) juga dapat menyebabkan ketahanan kariorespirasi terganggu karena kemampuan CO yang mengikat hemoglobin lebih kuat dibandingkan dengan oksigen sehingga dapat menimbulkan desaturasi hemoglobin di dalam darah dan menurunkan langsung persediaan oksigen untuk jaringan seluruh tubuh termasuk ke otot jantung. Karbon monoksida menggantikan tempat oksigen di hemoglobin dan mengganggu pelepasan oksigen, dengan demikian karbon monoksida menurunkan kapasitas pada latihan fisik. ${ }^{13}$

Berdasarkan penelitian juga didapatkan bahwa individu yang merokok memiliki ketahanan kardiorespirasi yang kurang baik. Hal ini terbukti pada sebuah penelitian yang dilakukan Erawati pada tahun 2014 di Riau yang mendapatkan ketahanan kardiorespirasi yang kurang pada individu yang merokok dengan pengukuran ketahanan kardiorespirasi yang sama yaitu Harvard Step Test. ${ }^{14}$ Perokok membutuhkan kinerja yang lebih besar karena pada perokok terjadi penurunan pada kinerja dan daya tahan kardiorespirasi. Jika dibandingkan pada individu yang tidak merokok, ketahanan kardiorespirasi pada perokok 7,2\% lebih kecil. Denyut nadi istirahat pada individu yang merokok lebih lebih tinggi dan denyut nadi maksimalnya lebih rendah daripada individu yang tidak merokok. Dengan kata lain, semakin tinggi denyut nadi istirahat, baik jantung maupun paru dari perokok harus bekerja lebih keras untuk memompakan darah ke seluruh tubuh sehingga individu tersebut akan cepat lelah. ${ }^{15}$ 


\section{KESIMPULAN}

Terdapat hubungan yang bermakna antara perilaku merokok dengan ketahanan kardiorespirasi siswa SMK N 1 Padang dimana pada siswa yang merokok memiliki ketahanan kardiorespirasi yang kurang baik dibandingkan dengan siswa yang tidak merokok.

\section{SARAN}

Perlu adanya kegiatan promotif dan preventif pada siswa sekolah menengah mengenai rokok dan bahaya yang ditimbulkan oleh rokok.

Perlu dilakukan penelitian tentang hubungan perilaku merokok dengan ketahanan kardiorespirasi dengan cakupan yang lebih luas yaitu pada sekolah lain di kota Padang.

Perlu dilakukan penelitian tentang hubungan perilaku merokok dengan ketahanan kardiorespirasi dengan pengambilan data perilaku merokok subjek penelitian menggunakan alat pengukur kadar $\mathrm{CO}$ di dalam paru.

\section{UCAPAN TERIMAKASIH}

Terima kasih kepada semua pihak atas bimbingan, bantuan dan motivasi dalam penelitian ini serta kepada pihak SMK N 1 Padang dan subjek penelitian yang telah berpartisipasi.

\section{DAFTAR PUSTAKA}

1. Komalasari D, Helmi AF. Faktor-faktor penyebab perilaku merokok pada remaja. Yogyakarta: Universitas Gadjah Mada Press; 2000.

2. Budiman. Masalah kesehatan akibat alkohol dan merokok. Dalam: Sudoyo AW, Setiyohadi B, Alwi L, Simadibrata MK, Setiati S, editor (penyunting). IImu Penyakit Dalam. Edisi ke-5. Jakarta: Pusat Penerbitan Departemen IImu Penyakit Dalam Fakultas Kedokteran Universitas Indonesia; 2009.

3. Smet B. Psikologi kesehatan. Semarang: PT Gramedia;1994.

4. Departemen Kesehatan Republik Indonesia. Riset kesehatan dasar 2013. Badan Penelitian dan Pengembangan Kesehatan. 2013 (diunduh 2 April 2014). Tersedia dari: URL: HYPERLINK http://www.litbang.depkes.go.id/sites/download/rkd 2013/Laporan Riskesdas2013.PDF

5. Komisi Perlindungan Anak Indonesia. Menyelamatkan anak dari bahaya rokok. 2011 (diunduh 22 Agustus 2013). Tersedia dari: URL: HYPERLINK http://www.kpai.go.id/tinjauan/ menyelamatkan-anak-dari-bahaya-rokok/

6. Komisi Perlindungan Anak Indonesia. Perlindungan dan pencegahan bahaya merokok pada anak. 2011 (diunduh 10 Mei 2013). Tersedia dari: URL: HYPERLINK http://www.kpai.go.id/ publikasi-mainmenu-33/press-release/41-perlin dungan-dan-pencegahan-bahaya-merokok-padaanak-.html?showall=1

7. World Health Organization (WHO). WHO report on the global tobacco epidemic the mpower package. Geneva: World Health Organization; 2008.

8. TCSC. Rokok mengapa haram. 2012 (diunduh 22 Agustus 2013). Tersedia dari: URL: HYPERLINK http://tcsc-indonesia.org/wp-content/uploads/2012/ 11/buku-Rokok-Mengapa-Haram-.pdf

9. Aula, Ellizabet L. Stop merokok. Yogyakarta: Garailmu. 2010.

10. Rahmawati I. Hubungan kebiasaan merokok dengan tingkat kebugaran jasmani di Dusun Taman Desa Taman Baru Taktakan Serang, Banten. Semarang: Universitas Diponegoro; 2009.

11. Budiasih KAS. Faktor-faktor yang mempengaruhi kebugaran jasmani karyawan PT. Amoco Mitsui Indonesia Tahun 2011 (skripsi). Jakarta: Universitas Pembangunan Nasional Veteran; 2011.

12. Tjandra H. Merokok dan Kesehatan 2003 (diunduh 17 Desember 2013). Tersedia dari: URL: HYPERLINK http://www.domeclinic.com/lifestyle/ merokok-a-kesehatan.-pdf

13. Theodorus. Ciri perokok di kalangan mahasiswa/i Universitas Sriwijaya. Jurnal Psikologi.1994;319-24

14. Erawati E. Hubungan kebiasaan merokok dengan ketahanan kardiorespirasi pada dosen pria Fakultas IImu Sosial dan IImu Politik Universitas Riau. Pekanbaru: Universitas Riau; 2014.

15. Compaign for tobacco free kids. smoking, physical activity and poor physical performance, 2004 (diunduh 20 September 2014). Tersedia dari: URL: HYPERLINK http://tobaccofreekids.org/ 